American Journal of Animal and Veterinary Sciences 6 (1): 18-24, 2011

ISSN 1557-4555

(C) 2011 Science Publications

\title{
The Ovario-Protective Effect of Erythropoietin against Oxidative Damage Associated with Reperfusion Following Ovarian Torsion in Rat
}

\author{
${ }^{1}$ Sayyah-Melli Manizheh, ${ }^{2}$ Kazemi-Shishvan Maryamalsadat, ${ }^{3}$ Solaimani-Rad Jafar, \\ ${ }^{4}$ Rashidi Mohammad-Reza, ${ }^{5}$ Roshangar Leila, ${ }^{6}$ Rashtchizadeh Nadereh, \\ ${ }^{7}$ Ouladesahebmadarek Elaheh, ${ }^{8}$ Ghojazadeh Morteza and ${ }^{9}$ Mashrabi Omid \\ ${ }^{1}$ Department of Obstetrics and Gynecology, \\ ${ }^{2}$ Department of the Medical, Faculty of Medicine, \\ ${ }^{3}$ Department of Embryology and Histology, Faculty of Medicine, \\ ${ }^{4}$ Department of the Medicinal Chemistry, Faculty of Pharmacy, \\ ${ }^{5}$ Department of Embryology and Histology, Faculty of Medicine, \\ ${ }^{6}$ Department of Biochemistry, \\ ${ }^{7}$ Department of Obstetrics and Gynecology, Alzahra Teaching Hospital, \\ ${ }^{8}$ Department of the Phisiology, Faculty of Medicine, \\ ${ }^{9}$ Department of the General Physician, Faculty of Medicine, \\ Tabriz University of Medical Sciences, Tabriz, Iran
}

\begin{abstract}
Problem statement: To show the effect of recombinant Erythropoietin (rhEPO) on the ovarian viability and histology in the twisted ischemic ovaries in rats, followed by detorsion. Approach: An experimental study was conducted in primate clinic of the School of Medicine, Tabriz University of Medical Sciences from Dec. 2008 to Apr. 2009. Forty, 4 month old Wistar rats are cased in the present study divided into 4 groups. Ovarian ischemia was performed by torsion which was kept stable by using a vascular microclip for $4 \mathrm{~h}$. In group 1, the ovary were surgically removed, fixed and analyzed histochemically. In group 2, the same procedure was repeated after $3 \mathrm{~h}$ reperfusion. In the next two groups, the same was performed rhEPO was administrated $400 \mathrm{u} \mathrm{kg}^{-1} 1 \mathrm{~h}$ after torsion of the ovaries. Results: Thirty-two out of 40 rats were followed. There was a significant difference between groups in the levels of Malondialdehyde (MDA), Total Antioxidants (TA), Superoxidase (SOD), Nitric Oxide (NO) glutathione $(\mathrm{p}<0.001)$. Addition of rhEPO maintained the normal histologic appearance in interventional groups compared with controls. Conclusion: Administration of rhEPO was effective in reducing the ischemic effect and free radicals damages of ovarian torsion in rats.
\end{abstract}

Key words: Ovarian torsion, Analysis Of Variance (ANOVA), Malondialdehyde (MDA), oxidative, cytokine, Superoxidase (SOD), ischemic effect

\section{INTRODUCTION}

Ovarian Torsion (OT) is one of the most encountered gynecological emergency requiring surgeries with an incidence of $3 \%$ in a series of acute gynecological complaints (Becker et al., 2009). To avoid complications and preserve future fertility, OT should be suspected at an early stage (Galinier et al., 2008). The preoperative findings of ovarian blood flow on Doppler sonography in cases with surgically proven adnexal torsion may be helpful in prediction of OT, but the accuracy remains low (Nizar et al., 2009). In routine practice, tends to remove adnexa to prevent embolism.
However, it seems that this intervention is not a good option for young women especially during the reproductive years. Galinier et al. (2009) showed that when the ovary was preserved after detorsion, the outcome is good conservative approach after detorsion of black-bluish ovaries is safe and effective. Regarding these observations even after immediate surgical intervention, however, when encountering with a twisted adnexa, the best intervention to save ovarian function has not been elucidated yet. Several antioxidant supplementations have been investigated in reducing the ischemic effect of OT on reperfusion injury in a controlled experimental rat torsion-

\section{Corresponding Author: Mashrabi Omid, Faculty of Medicine, Tabriz University of Medical Sciences, Tabriz,} Iran Tel: +98-9144049694/+98-4226226106 
detorsion model, including Melatonin (Turkoz et al., 2004; Labibzadeh and Sadrnejad, 2007a), Aprotinin (Sahin et al., 2008), $\alpha$-lipoic acid (Cosar et al., 2007), Genistein (Yazici et al., 2007), Iloprost (Ozat et al., 2009) Marrubium cordatum extract (Cigremis et al., 2009). Natural antioxidants have also been examined in testicular torsion. According to Unsal et al. (2006), dietary supplementation with Garlic Extract (GE) seems to attenuate the generation of toxic free radicals, as evidenced indirectly by low tissue MDA levels. EPO has been proved to be a multiple functional cytokine to attenuate Ischemia-Reperfusion $(\mathrm{I} / \mathrm{R})$ injury in various organs. In addition, the antioxidant effect of EPO has been demonstrated in a number of tissues (Sharples et al., 2004; Calvillo et al., 2003; Wu et al., 2006; Labibzadeh and Sadrnejad, 2007b). EPO and its Receptors (EPOR) have also been recognized to be essential for the survival, proliferation differentiation of erythroid progenitor cells (Calvillo et al., 2003; Labibzadeh et al., 2008). Based on these findings and other observations, we designed the present study to investigate the anti-oxidative effects of rhEPO and its possible usefulness for the ovarian protection at torsion in rat ovarian tissue. The histopathological changes together with oxidant status of rat ovaries before and after administration of EPO will also be covered.

\section{MATERIALS AND METHODS}

An experimental study was conducted from December 2008 to April 2009. Forty, 4 month old Wistar rats are cased in the study divided into 4 groups by simple randomization. All rats were anesthetized with Ketamine $\left(5 \mathrm{mg} \mathrm{kg}^{-1}\right)$ and $0.2 \mathrm{ml}$ diazepam anesthesia was maintained by supplementary intraperitoneally Ketamin. The anesthetized rats were placed onto a thermostatically controlled heating mat and body temperature maintained at $37 \pm 0.5^{\circ} \mathrm{C}$ by means of a rectal probe attached to a homoeothermic blanket. A midline laparotomy was performed in order to carefully expose the ovaries.

The blood supply of the right ovaries, both artery and vein circulation, was interrupted by its torsion and the torsion was kept stable by using a vascular microclip. The ovary was fixed on the abdominal wall. The wound was closed by clips. Occlusion was verified visually by changing in the color of the ovary to a paler shade and reperfusion by a blush. At the end of all experiments, rats were sacrificed by an overdose of anesthetic.
Rats were housed and fed at the Animal Center of School of Medicine, before surgery for adaptation with the environment. All animals' procedures complied with an approved Tabriz University of Medical Sciences' animal care and use committee. The rhEPO (PD poetin) was purchased from Pooyesh Darou Pharmaceutical Co Iran. The study protocol was reviewed and approved by the Tabriz Research Affair Review Board.

Animals were randomly allocated into four groups as follow: In group 1: rats were subjected to the surgical procedures described above. Following an ischemic period of $4 \mathrm{~h}$, the occluded adnexa was surgically removed and the ovaries were harvested for histopathological and biochemical studies. Then the rats were sacrificed. In group 2, the same procedure was repeated. The clips were removed and the ovaries detorsioned and allowed for reperfusion for $3 \mathrm{~h}$, then surgically were removed. In the next two groups, the same procedure was performed and rhEPO $\left(400 \mathrm{u} \mathrm{kg}^{-1}\right)$ was administrated intraperitoneally $1 \mathrm{~h}$ after occlusion of the ovarian vessels. The dose of rhEPO was chosen based on the findings of Villa et al., 2003; Bonakdar et al., 2007).

Measurement of biochemical parameters: After performing surgery, at the end of ischemic period and also at the end of the reperfusion period, the ovaries surgically have been removed in each group and fixed for biochemical examination. A part was fixed in $10 \%$ formalin neutral buffered for histological examination. Samples were transported in liquid nitrogen and kept frozen at $-70^{\circ} \mathrm{C}$.

Malondialdehyde (MDA) level as an index of lipid peroxidation was measured by the Thiobarbituric Acid (TBA) method (26). Superoxidase activities (SOD) were measured spectrophotometrically with RANSOD test kits (obtained from Randox Laboratories Ltd). Total Antioxidants (TA) was determined with the RANDOX kit. Plasma glutathione levels were measured by Cayman Immuno enzyme assay kit (LOT. 7032002). NO was measured spectrophotometrically by Miranda K.M method. In this method at first NO produce nitrate and nitrite. At second step simultaneous evaluation of nitrate and nitrite concentrations involves reduction of nitrate by vanadium (III) and detection with Griess reagents (Miranda et al., 2001).

Histopathological analysis: At the end of each experiment, a part of ovary fixed in $10 \%$ buffered formalin, embedded in paraffin, cut into $4 \mu \mathrm{m}$ sections 
stained with haematoxylin-eosin for histopathological analyzes vascular dilatation, interstitial edema, hemorrhage, PMN infiltration were examined and photomicrograph were taken.

All data are presented as means $\pm \mathrm{SD}$. Intragroup comparison was carried out using the Turkey Post Hoc test and One-way Analysis Of Variance (ANOVA). A 95\% Confidence Interval (CI) for independent variables was calculated. For all statistical analyses, the differences were considered statistically significant at $\mathrm{p}<0.05$. To evaluate the distributions, box-and whisker plots and the Kolmogorov-Smirnow (K-S) test of normality were used. The statistical analysis was performed by Statistical Package for Social Sciences program (SPSS version 15.0 for Windows).

\section{RESULTS}

Forty rats included, 8 of them demised and 32 of them ( 8 in each group) were eligible to follow-up. The results of biochemical analysis are shown in Table 1. The results of one-way ANOVA test show significant differences between 4 groups in the mean levels of MDA $\left.\left[\left(\mathrm{F}_{3,27}\right)=65.54, \mathrm{p}<0.001\right)\right]$, TA $\left[\left(\mathrm{F}_{3,27}\right)=17.91\right.$, $\mathrm{p}<0.001)]$, SOD $\left.\left[\left(\mathrm{F}_{3,27}\right)=13.96, \mathrm{p}<0.001\right)\right]$, NO $\left.\left[\left(\mathrm{F}_{3,27}\right)=18.35, \mathrm{p}<0.001\right)\right]$ glutathione $\left[\left(\mathrm{F}_{3,27}\right)=77.89\right.$, $\mathrm{p}<0.001)]$. According to the results of Turkey Post Hoc test analysis, there were significant differences between group 1 and other groups $(\mathrm{p}<0.001)$ at the levels of MDA. In addition, the same test shows significant difference between mean MDA of group 2 with other groups $(p<0.03)$, but the mean difference between group 3 with group 4 which both had been received EPO, was not significant $(p=0.99)$ (Fig. 1). The data from this comparison for TA levels showed significant difference between group 1 and other groups $(p<0.027)$, no significant difference between group 2 with group 3 $(\mathrm{p}=0.13)$, significant difference between group 2 with other groups $(p<0.027)$ no significant difference between group 3 with groups 2 and $4(p>0.13)$. For SOD, there was no significant difference between group 1 and $2(p=0.49)$, no significant difference between group 3 with group 2 and $4(\mathrm{p}>0.13)$ also no significant difference between group 2 with group 1 and 3 $(\mathrm{p}>0.08)$. But the mean difference between group 2 with group 4 was statistically significant $(p=0.01)$.

In addition, according to our data for NO, there was no significant difference between group 1 and $2(\mathrm{p}$ $=0.93)$, with group 3 and group $4(p=0.17)$, but it was significant between group 3 and $4(p<0.001)$ group 2 with group 3 and $4(p<0.004)$ (Fig. 2).

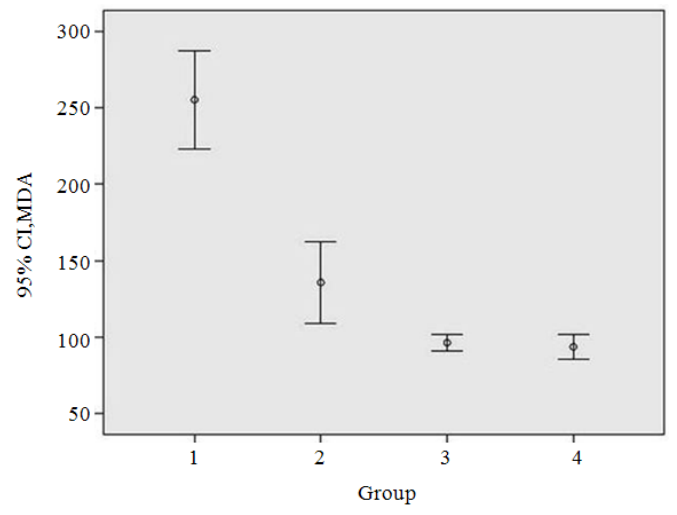

Fig. 1: The changes at the mean levels of MDA in the right ovary of studied groups. MDA: Malondialdehyde, 95\% CI: 95\% confidence interval.1: Group 1: The ovary was removed $4 \mathrm{~h}$ after occlusion. 2: Group 2: The ovary was allowed for reperfusion unit $3 \mathrm{~h}$ after $4 \mathrm{~h}$ ischemic period, then removed. Group 3: rhEPO $\left(400 \mu \mathrm{kg}^{-1}\right)$ was administrated intraperitoneally $1 \mathrm{~h}$ after occlusion of the ovary. The ovary was removed $4 \mathrm{~h}$ after occlusion. Group 4: rhEPO $\left(400 \mu \mathrm{kg}^{-1}\right)$ was administrated intraperitoneally $1 \mathrm{~h}$ after occlusion of the ovary. The ovary was allowed for reperfusion until $3 \mathrm{~h}$ after $4 \mathrm{~h}$ ischemic period, then removed

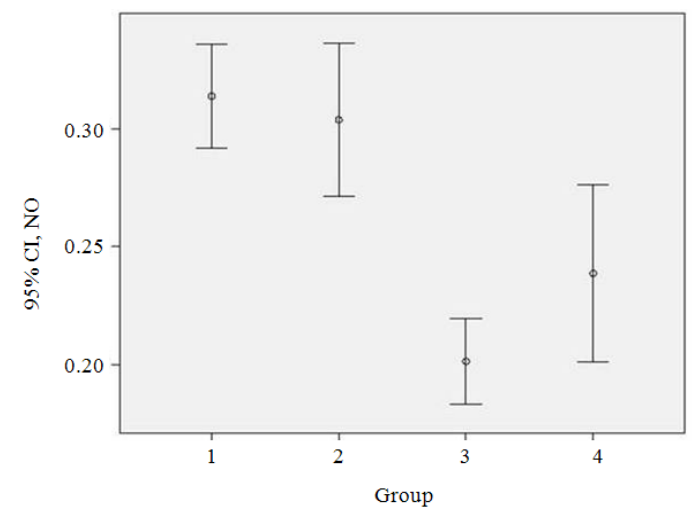

Fig. 2: The changes at the mean levels of NO in the right ovary of studied groups. NO: Nitric Oxide, 95\% CI: 95\% confidence interval.1: Group 1: the ovary was removed $4 \mathrm{~h}$ after occlusion. 2: Group 2: The ovary was allowed for reperfusion unit 3 $\mathrm{h}$ after $4 \mathrm{~h}$ ischemic period, then removed. Group 3: $\operatorname{rhEPO}\left(400 \mu \mathrm{kg}^{-1}\right)$ was administrated intraperitoneally $1 \mathrm{~h}$ after occlusion of the ovary. The ovary was removed $4 \mathrm{~h}$ after occlusion. Group 4: rhEPO $\left(400 \mu \mathrm{kg}^{-1}\right)$ was administrated intraperitoneally $1 \mathrm{~h}$ after occlusion of the ovary. The ovary was allowed for reperfusion until $3 \mathrm{~h}$ after $4 \mathrm{~h}$ ischemic period, then removed 


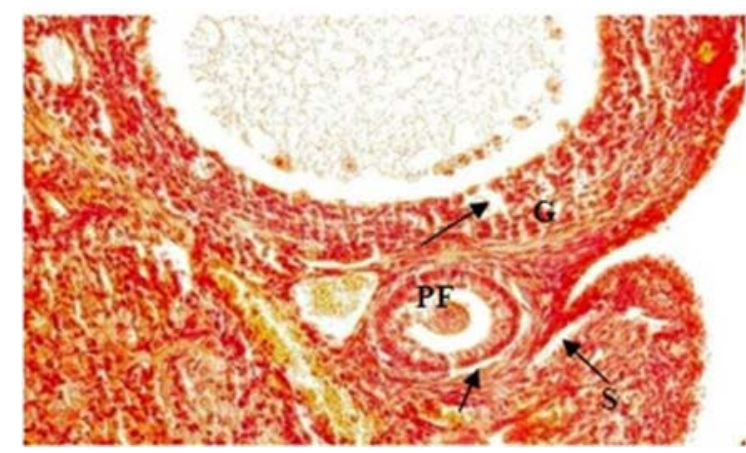

Fig. 3: A section from ovary $4 \mathrm{~h}$ after torsion showing parts of an antenatal follicle and a late Primary Follicle (PF). As the figure shows the Granulose (G) and Stormal (S) cells are separated by accumulation of extra cellular fluid, in the oocyte, perivitelline space is enlarged and oocyte is in a degenerating starus. (haematoxyli-eosin, original magnification 3100)

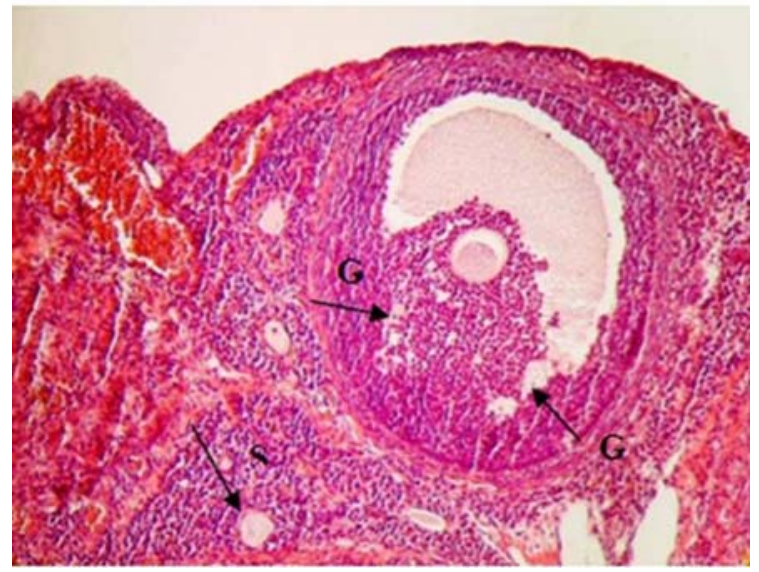

Fig. 4: A section from ovary torsion $4 \mathrm{~h}$ and removed after $3 \mathrm{~h}$. Postdetorsioning anantenatal follicle is present in the figure with the ovarian stromal cells (S) and follicular granulose (G). The granulose and strromal cells are separated by extra cellular fluid. The oocyte has a degenerating appearance and zona pellucid looks very thin. (haematoxyli-eosin, original magnification 3100)

There was also significant difference between mean levels of glutathione between group 1 and other groups $(p<0.001)$, but there were no significant differences between mean levels of glutathione between group 3 and group $4(\mathrm{p}=0.97)$. Histopathological changes of ovarian stroma and follicles are shown in Fig. 3-6.

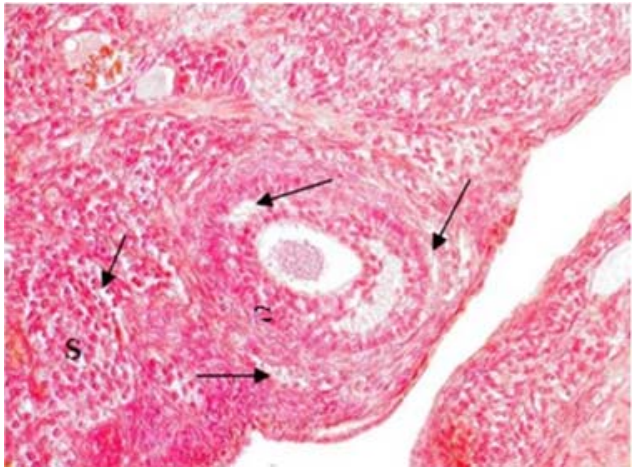

Fig. 5: Received erythropoietin $1 \mathrm{~h}$ after torsion. Ovary removed $4 \mathrm{~h}$ after torsion. The granulose $(\mathrm{G})$ and Stormal cells (S) are separated from each other. The cells in Storma (S) and Granulose layer $(\mathrm{G})$ are normal in size but intercellular space are enlarged (arrow). (haematoxyli-eosin, original magnification 3100)

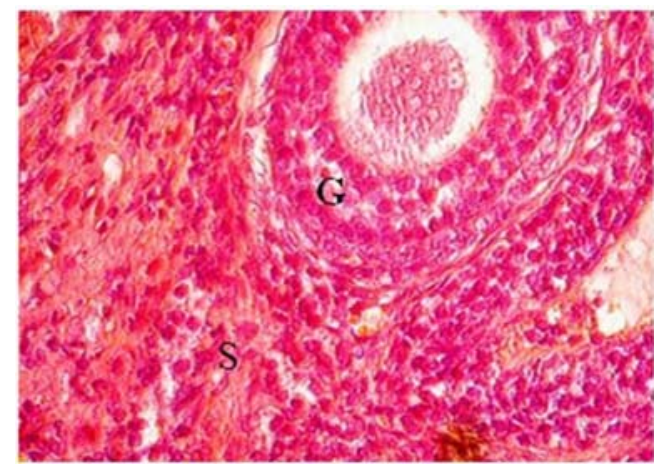

Fig. 6: A section from ovary $3 \mathrm{~h}$ after detorsion, which received EPO $1 \mathrm{~h}$ after torsion. The Stromal (S) and Granulosa cells (G) and ECM appears almost normal, indicating protective effect of erythropoietin injection. Zona pellucid has normal width and oocyte looks normal. (haematoxyli-eosin, original magnification 3100)

\section{DISCUSSION}

Although considerable progress has been made in the diagnosis and treatment of ovarian torsion, the problem remains as a challenging issue, often leading to delayed operative intervention and resultant ovarian loss (Oltmann et al., 2009). To preserve the ovarian function, treatment of torsion should be as conservative as possible (Rousseau et al., 2008). RhEPO which was used in this study has several beneficial effects in ischemic organs (Sharples et al., 2004; Bonakdar et al., 2007; Calvillo et al., 2003; Wu et al., 2006). EPO is a 
potent antioxidant (Asli-Ardeh and AbbaspourGilandeh, 2008). From the findings of this study, rhEPO exerted an antioxidant effect in reducing ischemia/reperfusion induced tissue damage in ovary. The data also showed an increase in the tissue levels of MDA after ovarian torsion which, in turn, probably resulted in ovarian tissue damage by means of lipid peroxidation (Fig. 3 and 4). According to Celik et al. (2004), MDA is a marker of tissue injury increased levels of it reflect the destruction of unsaturated fatty acids in the cell membrane. In our study, administration of rhEPO significantly reduced the oxidant levels within the ovary (Table 1) a reduction at the levels of MDA, prevented post-ischemic ovarian injury and maintained the ovarian morphology (Fig. 5 and 6). Therefore, based on these results, the beneficial effects of rhEPO could be attributed, at least in part, to a reduction in the oxidative injury to ovarian cellular tissue and a stimulatory effect on SOD, NO, TA and glutathione (Table 1). Histopathologically, we determined that EPO group was better than controls with normal histopathologic appearance (Fig. 5 and 6). One possible explanation for these findings is the ability of rhEPO to protect the tissues from damages associated with hypoxia. The histological and biochemical results in the present study are in agreement with those reports which suggest administration of EPO for reduction of oxidative stress in other organs (Sharples et al., 2004; Calvillo et al., 2003; Wu et al., 2006; Nejat et al., 2009; Karami et al., 2009).

The role of Erythropoietin-Erythropoietin-Receptor (EPO-EPO-R) system in the cellular survival pathway has also been well recognized (Aydin et al., 2007). EPO is a tissue-protective cytokine this seems to be true for all organs expressing the EPO receptor. The antioxidative effects of EPO have also demonstrated by Katavetin et al. (2007). According to these authors, the antioxidative properties of EPO may arise from its direct effect on intracellular antioxidative mechanisms such as heme oxygenase-1 and glutathione peroxidase. It is also possible that EPO induces iron depletion and thereby inhibiting iron-dependent oxidative injury. In addition, it has been suggested that EPO can increase red blood cells leading to a reduction in cellular oxidative stress. According to the literature, EPO also exerts its beneficial effect in ischemic organs by prevention of apoptosis, probably by increasing $\mathrm{Bcl} 2$ and HSP70 expression (Celik et al., 2004; Bonakdar et al., 2007). The time which the tissue exposing to ischemia is critical. Calvillo et al. (2003; Bonakdar et al., 2007), in an experimental study on myocardial cells showed that rhEPO prevents apoptosis when the cells exposed to extreme and prolonged hypoxia. In their study reduction of medium oxygen content to $<1 \%$ triggered a majority of cells to enter in apoptosis. It appears that the ovaries have high resistance to ischemia (Ming et al., 2001; Bonakdar et al., 2007). EPO is a protective tissue cytokine it's receptors have been shown to exist in lots of tissues. The antiinflammatory effect, angiogenesis anti-apoptosis pleiotropic effects of EPO make possible the clinical application of it. As a result, rhEPO mediated resistance of tissues to damage may help to account for the increased cell survival. In addition, when dealing with $\mathrm{I} / \mathrm{R}$, a potential role for rhEPO is the recruitment of stem cells into the region of injury (Shringo et al., 2001). Its safety has also been demonstrated in orthopedic surgeries (Shringo et al., 2001) shock management (Calvillo et al., 2003; Nejat et al., 2009). Tissue protective properties of erythropoietin as a hematopoietic growth factor are also recognized in preterm infants and term neonates by inhibition the production of various cytokines (Santoro et al., 2007). The main concept that emerges from our study and above observations is that rhEPO induces a tolerance of the ovary and other organs to a subsequent insult with I/R. However, these findings are not ignoring the importance of early diagnosis, conservative surgical and medical management in OT. More studies are necessary to be conducted to show the effect of erythropoietin at a longer time from occlusion. In addition, to implement administration of EPO against oxidative damage associated with reperfusion, clinical studies will be necessary to examine the therapeutic properties of rhEPO in patients with ovarian torsion.

Table 1: The results of biochemical analysis

\begin{tabular}{|c|c|c|c|c|c|}
\hline Group & $\begin{array}{l}\text { MDA mean } \pm \mathrm{SD}_{\dagger}^{\dagger} \\
(95 \% \mathrm{CI}) \ddagger \\
(\mathrm{p}<0.001)^{*}\end{array}$ & $\begin{array}{l}\text { TAO mean } \pm \text { SD } \\
(95 \% \mathrm{CI}) \\
(\mathrm{p}=<0.001)\end{array}$ & $\begin{array}{l}\text { SOD mean } \pm \text { SD } \\
(95 \% \mathrm{CI}) \\
(\mathrm{p}<0.001)\end{array}$ & $\begin{array}{l}\text { NO mean } \pm \text { SD } \\
(95 \% \mathrm{CI}) \\
\mathrm{p}<0.001)\end{array}$ & $\begin{array}{l}\text { Glutathione mean } \pm \text { SD } \\
(95 \% \mathrm{CI}) \\
(\mathrm{p}<0.001)\end{array}$ \\
\hline 1 & $\begin{array}{l}255.19 \pm 38.62 \\
(222.90-287.48)\end{array}$ & $\begin{array}{l}0.53 \pm 0.13 \\
(0.42-0.64)\end{array}$ & $\begin{array}{l}0.45 \pm 0.02 \\
(0.43-0.47)\end{array}$ & $\begin{array}{l}0.31 \pm 0.02 \\
(0.29-0.33)\end{array}$ & $\begin{array}{l}198.63 \pm 15.80 \\
(185.41-211.84)\end{array}$ \\
\hline 2 & $\begin{array}{l}135.75 \pm 32.15 \\
(108.87-162.63)\end{array}$ & $\begin{array}{l}0.99 \pm 0.20 \\
(0.82-1.16)\end{array}$ & $\begin{array}{l}0.49 \pm 0.01 \\
(0.47-0.51)\end{array}$ & $\begin{array}{l}0.30 \pm 0.03 \\
(0.27-0.33)\end{array}$ & $\begin{array}{l}277.55 \pm 43.07 \\
(241.74-313.76)\end{array}$ \\
\hline 3 & $\begin{array}{l}96.43 \pm 5.99 \\
(90.88-101.97)\end{array}$ & $\begin{array}{l}1.35 \pm 0.35 \\
(1.02-1.67)\end{array}$ & $\begin{array}{l}0.57 \pm 0.05 \\
(0.52-0.62)\end{array}$ & $\begin{array}{l}0.20 \pm 0.01 \\
(0.18-0.21)\end{array}$ & $\begin{array}{l}451.86 \pm 46.96 \\
(408.67-495.04)\end{array}$ \\
\hline 4 & $\begin{array}{l}93.63 \pm 9.91 \\
(85.34-101.91)\end{array}$ & $\begin{array}{l}1.58 \pm 0.43 \\
(1.22-1.95)\end{array}$ & $\begin{array}{l}0.53 \pm 0.8 \\
(0.54-0.70)\end{array}$ & $\begin{array}{l}0.23 \pm 0.04 \\
(0.20-0.27)\end{array}$ & $\begin{array}{l}443.88 \pm 45.25 \\
(406.05-481.70)\end{array}$ \\
\hline
\end{tabular}


The results showed that the erythropoietin was effective in reducing the ischemic effect of ovarian torsion in female rats. Histochemical changes show that adnexal integrity is maintained at the presence of prompt surgical and medical intervention. To bring this entity and its great variability in clinical presentation into focus once again, we are highlighting the importance of subject. Taken together, the data presented in this report provide important information in regard to the possible effect of EPO. Further researches to examine the effect of rhEPO in human ovarian torsion are recommended.

\section{CONCLUSION}

These study was funded by a grant from Research Vice-Chancellor of Tabriz University of Medical Sciences, Iran (Project No: 8718). The author(s) also declare that they have no conflicting interests, or funding by any Drug Company.

\section{ACKNOWLEDGEMENT}

We thank and fully acknowledge the staff of primate center of Medical School of Tabriz University of Medical Sciences for their help our special, thanks to Women's Reproductive Health Research Center affiliated to the Tabriz University of Medical Sciences Research Affairs for supporting this study.

\section{REFERENCES}

Asli-Ardeh, E.A. and Y. Abbaspour-Gilandeh, 2008. Investigation of the effective factors on threshing loss, damaged grains percent and material other than grain to grain ratio on an auto head feed threshing unit. Am. J. Agric. Biol. Sci., 3: 699-705. DOI: 10.3844/ajabssp.2008.699.705

Aydin, Z., J. Duijs, I.M. Bajema, A.J. Van Zonneveld and T.J. Rabelink, 2007. Erythropoietin, progenitors, and repair. Kidney Int. Suppl., 72: 16-20. DOI: $10.1038 /$ sj.ki.5002483

Becker, J.H., J. de Graaff, C.M. Vos, 2009. Torsion of the ovary: A known but frequently missed diagnosis. Eur. J. Emerg Med., 16: 124-126. DOI: 10.1097/MEJ.0b013e32831cbaf8

Bonakdar, A., J. Dargahi and R. Bhat, 2007. Investigations on the grasping contact analysis of biological tissues with applications in minimally invasive surgery. Am. J. Applied Sci., 4: 1016-1023. DOI: 10.3844/ajassp.2007.1016.1023

Calvillo, L., R. Latini, J. Kajstura, A. Leri and P. Anversa et al., 2003. Recombinant human erythropoietin protects the myocardium from ischemiareperfusion injury and promotes beneficial remodeling. Proc. Nat. Acad. Sci. USA., 100: 4802-4806. DOI: 10.1073/pnas.0630444100
Celik, O., Y. Turkoz, S. Hascalik, M. Hascalik and Y. Cigremis et al., 2004. The protective effect of caffeic acid phenethyl ester on ischemiareperfusion injury in rat ovary. Eur. J. Obstet. Gynecol. Reprod., 117: 183-188. DOI: 10.1016/j.ejogrb.2004.05.007

Cigremis, Y., A. Kart, M. Karaman and D. Erdag, 2009. Attenuation of ischemia-reperfusion injury with Marrubium cordatum treatment in ovarian torsiondetorsion model in rabbits. Fertil Steril, 93: 14551463. DOI: 10.1016/j.fertnstert.2009.03.041

Cosar, E., F.K. Sahin, G. Koken, H. Toy and K. Basarali et al., 2007. The protective effect of $\alpha$ lipoic acid in experimental ovarian ischaemiareperfusion injury. Aust. N. Z. J. Obstet. Gynaecol., 47: 499-503. DOI: 10.1111/j.1479828X.2007.00787.x

Galinier, P., L. Carfagna, M. Delsol, Q. Ballouhey and F. Lemasson et al., 2009. Ovarian torsion. Management and ovarian prognosis: A report of 45 cases. J. Pediatr. Surg., 44: 1759-1765. PMID: 19735822

Galinier, P., L. Carfagna, M. Juricic, F. Lemasson and J. Moscovici et al., 2008. Fetal ovarian cysts management and ovarian prognosis: A report of 82 cases. J. Pediatr. Surg., 43: 2004-2009. PMID: 18970932

Karami, A., Z.A.M. Ahmad and K. Sijam, 2009. Morphological characteristics and pathogenicity of synchytrium psophocarpi (Rac.) baumann associated with false rust on winged bean. Am. J. Applied Sci., 6: 1876-1879. DOI: 10.3844/ajassp.2009.1876.1879

Katavetin, P., K. Tungsanga, S. Eiam-Ong, M. Nangaku, 2007. Antioxidative effects of erythropoietinAntioxidative effects of EPO. Kidney Int. Suppl., 72: 10-15. DOI: 10.1038/sj.ki.5002482

Labibzadeh, M. and S.A. Sadrnejad, 2007a. Mesoscopic damage based model for plane concrete under static and dynamic loadings. Am. J. Applied Sci., 3: 2011-2019. DOI: 10.3844/ajassp.2006.2011.2019

Labibzadeh, M. and S.A. Sadrnejad, 2007b. Crack analysis of concrete arch dams using micro-planes damage based constitutive relations. Am. J. Applied Sci., 4: 197-202. DOI: 10.3844/ajassp.2007.197.202

Labibzadeh, M., S.A. Sadrnejad and M. Naisipour, 2008. An assessment of compressive size effect of plane concrete using combination of micro-plane damage based model and $3 \mathrm{~d}$ finite elements approach. Am. J. Applied Sci., 5: 106-109. DOI: 10.3844/ajassp.2008.106.109 
Ming, C., C. Chin-Der and Y. Yu-Shih, 2001. Torsion of the previously normal uterine adnexa-evaluation of the correlation between the pathological changes and the clinical characteristics. Acta Obstetricia Gynecol. Scandinavica, 80: 58-61.

Miranda, K.M., M.G. Espey and D.A. Wink, 2001. A rapid, simple spectrophotometric method for simultaneous detection of nitrate and nitrite. Nitric. Oxide, 5: 62-71. DOI: 10.1006/niox.2000.0319

Nejat, N., K. Sijam, S.N.A. Abdullah, G. Vadamalai and M. Dickinson, 2009. Molecular characterization of a phytoplasma associated with Coconut Yellow Decline (CYD) in Malaysia. Am. J. Applied Sci., 6: 1331-1340. DOI: 10.3844/ajassp.2009.1331.1340

Nizar, K., M. Deutsch, S. Filmer, B. Weizman and R. Beloosesky et al., 2009. Doppler studies of the ovarian venous blood flow in the diagnosis of adnexal torsion. J. Clin. Ultrasound, 37: 436-439. DOI: $10.1002 /$ jcu.20621

Oltmann, S.C., A. Fischer, R. Barber, R. Huang and B. Hicks et al., 2009. Cannot exclude torsion-a 15year review. J. Pediatr. Surg., 44: 1212-1216. DOI: 10.1016/j.jpedsurg.2009.02.028

Ozat, M, T. Gungor, S. Barun, B. Demirogullari and L.K. Sokmensuer et al., 2009. The effects of iloprost, a prostacyclin analogue, in experimental ischaemia/reperfusion injury in rat ovaries. Exp. Toxicol. Pathol., 61: 519-527. DOI: 10.1016/j.etp.2009.06.007

Rousseau, V., R. Massicot, A.A. Darwish, F. Sauvat and S. Emond et al., 2008. Emergency management and conservative surgery of ovarian torsion in children: a report of 40 cases. J. Pediatr. Adolesc. Gynecol., 21: 201-206. DOI: 10.1016/j.jpag.2007.11.003

Sahin, F.K., E. Cosar, G. Koken, H. Toy and K. Basarali et al., 2008. Protective effect of aprotinin on ischemia-reperfusion injury in rat ovary. $\mathrm{J}$. Obstet. Gynaecol. Res., 34: 794-800. DOI: $10.1111 / \mathrm{j} .1447-0756.2008 .00846 . x$
Santoro, J.E., R.K. Eastlack, J.M. Mirocha and W.D. Bugbee, 2007. Impact of erythropoietin on allogenic blood exposure in orthopedic surgery. Am. J. Orthop., 36: 600-604. PMID: 18075608

Sharples, E.J., N. Patel, P. Brown, K Stewart and H. Mota-Philipe et al., 2004. Erythropoietin protects the kidney against the injury and dysfunction caused by ischemia-reperfusion. J. Am. Soc. Nephrol., 15: 2115-2124. DOI: 10.1097/01.ASN.0000135059.67385

Shringo, T., S. Sorokan, T. Shimazaki and S. Weiss, 2001. Erythropoietin regulates the in vitro and in vivo production of neuronal progenitors by mammalian forebrain neural stem cells. J. Neurosci., 21: 9733-9743.

Turkoz, Y., O. Celik, S. Hascalik, Y. Cigremis and M. Hascalik et al., 2004. Melatonin reduces torsiondetorsion injury in rat ovary: Biochemical and histopathologic evaluation. J. Pineal. Res., 37: 137-141. DOI: 10.1111/j.1600-079X.2004.00146.x

Unsal, A., M. Eroglu, A. Avci, E. Cimentepe and C. Guven et al., 2006. Protective role of natural antioxidant supplementation on testicular tissue after testicular torsion and detorsion. Scand J. Urol. Nephrol., 40: 17-22.

Villa, P., P. Bigini, T. Mennini, D. Agnello and T. Laragione et al., 2003. Erythropoietin selectively attenuates cytokine production and inflammation in cerebral ischemia by targeting neuronal apoptosis. J. Exp. Med., 198: 971-975. DOI: $10.1084 /$ jem.20021067

Wu, H., B. Ren, J. Zhu, G. Dong and B. Xu et al., 2006. Pretreatment with recombined human erythropoietin attenuates ischemia-reperfusioninduced lung injury in rats. Eur. J. Cardiothorac. Surg., 29 : 902-907. DOI: 10.1016/j.ejcts.2006.02.036

Yazici, G., O. Erdem, B. Cimen, M. Arslan and B. Tasdelen et al., 2007. Genistein attenuates postischemic ovarian injury in a rat adnexal torsion-detorsion model. Fertil Steril, 87: 391-396. DOI: 10.1016/j.fertnstert.2006.06.056 